\title{
Article \\ Structure and Content Analysis of Raw Materials for Production of Trimanganese Tetraoxide Pigment
}

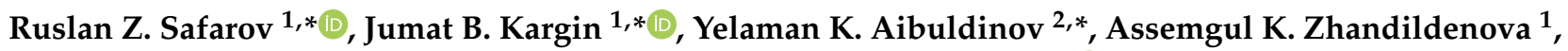 \\ Bolat B. Makhmutov ${ }^{3}$, Alexandr K. Sviderskiy ${ }^{4}$ and Nikolai I. Vatin ${ }^{5, *}$ (D) \\ 1 Department of Chemistry, Faculty of Natural Sciences, L.N. Gumilyov Eurasian National University, \\ Nur-Sultan 010000, Kazakhstan; zh_as80@mail.ru \\ 2 Department of Chemistry and Chemical Technologies, Faculty of Natural and Agricultural Sciences, \\ Kh. Dosmukhamedov Atyrau University, Atyrau 060011, Kazakhstan \\ 3 Department of General Education Disciplines, Faculty of Economics and Construction, \\ Karaganda Industrial University, Temirtau 101400, Kazakhstan; bolat200@mail.ru \\ 4 Faculty of Engineering and Technology, Innovative University of Eurasia, Pavlodar 140000, Kazakhstan; \\ katsostud@rambler.ru \\ 5 World-class Research Center for Advanced Digital Technologies, Peter the Great St. \\ Petersburg Polytechnic University, 195251 St. Petersburg, Russia \\ * Correspondence: ruslanbox@yandex.ru (R.Z.S.); kjb_orken@mail.ru (J.B.K.); elaman_@mail.ru (Y.K.A.); \\ vatin@mail.ru (N.I.V.)
}

check for updates

Citation: Safarov, R.Z.; Kargin, J.B.; Aibuldinov, Y.K.; Zhandildenova,

A.K.; Makhmutov, B.B.; Sviderskiy, A.K.; Vatin, N.I. Structure and Content Analysis of Raw Materials for Production of Trimanganese Tetraoxide Pigment. Crystals 2021, 11, 1460. https://doi.org/10.3390/ cryst11121460

Academic Editors: Guido J. Reiss and Leonid Kustov

Received: 17 October 2021

Accepted: 24 November 2021

Published: 26 November 2021

Publisher's Note: MDPI stays neutral with regard to jurisdictional claims in published maps and institutional affiliations.

Copyright: (c) 2021 by the authors. Licensee MDPI, Basel, Switzerland. This article is an open access article distributed under the terms and conditions of the Creative Commons Attribution (CC BY) license (https:// creativecommons.org/licenses/by/ $4.0 /)$.

\begin{abstract}
The research aims to reveal the structure, phase, and elemental content of manganese ores from deposits-Bogach (Karaganda region, Kazakhstan) and Zhaksy (Akmola region, Kazakhstan). The samples were studied with scanning electron microscopy with energy dispersive analysis (SEMEDA), X-ray diffractometry (XRD), Infra-red spectroscopy (IRS). During the research, structural peculiarities, elemental and phase content of the samples have been revealed. The mineral matter of the Bogach deposit ore mainly consists of hollandite, cryptomelane, braunite, calcite, bixbyite, quartz. The Zhaksy deposit ore includes quartz, hollandite, bixbyite, pyrolusite. Bogach ore includes (wt.\%) C(10.68), O(32.00), Mn(43.26), Ca(6.36), Si(3.51), Na(0.52), $\mathrm{Al}(1.13), \operatorname{Mg}(0.69), \mathrm{K}(1.85)$. The elemental content of $\mathrm{Mn}$ in Zhaksy ore is two times lower. Zhaksy ore includes (wt.\%) C(23.77), $\mathrm{O}(32.1), \mathrm{Mn}(21.81), \mathrm{Si}(10.52), \mathrm{Al}(5.13), \mathrm{K}(1.21), \mathrm{Fe}(5.47)$. The obtained data of the conducted spectral analysis indicate that both samples represent a polymineral heterogeneous structure. Conducted research allows to conclude, that by phase-elemental content the Bogach ore can be used for obtaining trimanganese tetraoxide pigment similar to manganese ores from West Sumatera deposit (Indonesia) by top-down method using grinding with a milling tool and high-temperature sintering.
\end{abstract}

Keywords: trimanganese tetraoxide; hausmannite; manganese ore; XRD; SEM; EDA; IR spectroscopy; Zhaksy; Bogach

\section{Introduction}

Trimanganese tetraoxide is the chemical compound with the formula $\mathrm{Mn}_{3} \mathrm{O}_{4}$. It is also known as hausmannite [1]. Hausmannite belongs to a group of the $\mathrm{Mn}^{2+} \mathrm{Mn}_{2}{ }^{3+} \mathrm{O}_{4}$ oxides. These oxides include $\mathrm{Mn}(\mathrm{II})$ and $\mathrm{Mn}$ (III) in a tetragonal crystal. Hausmannite is a stable mineral due to its crystal structure [2].

Hausmannite has a lot of applications in the industry. The application of hausmannite depends on the purity and granulometric fraction of the sample. As an example, a high disperse hausmannite can be used in steel production as an alloying additive [3]. This alloying additive is used to slow down the corrosion processes in metals. Anticorrosive compounds containing $\mathrm{Mn}_{3} \mathrm{O}_{4}$ form a thin layer on the metal surface and improve its resistance to different agents such as water, air and other chemical compounds. Hausmannite also can be used as a colorant, a nonmetallic paint or varnish [4].This treatment is highly effective especially on the metals initial damage stage [5]. 
The wide range of hausmannite applications can be seen in various scientific publications. For instance $\mathrm{Mn}_{3} \mathrm{O}_{4}$ was used as a catalytic agent [6], as an active component of filters [7], as a component for electrodes [8-11], and as a water purification material [12]. At the same time this chemical element shows antibacterial [13], photocatalytic [13,14], electrochemical $[15,16]$ and magnetic $[17,18]$ properties.

Hausmannite is widely used for staining of ceramic products from red or white calcined clay, which can be used at high temperatures of $800-1200{ }^{\circ} \mathrm{C}$. It is also used as a colorant to produce light brown, brown, as well dark brown ceramic products such as tiles and bricks. A distinctive feature of Mn colorants of high quality is high content of Mn, homogeneity, low dust formation, and high level of quality.

Different ways of laboratory hausmannite production are described in scientific articles. The nano-sized $\mathrm{Mn}_{3} \mathrm{O}_{4}$ can be prepared by applying two main methods: "bottom-up" and "top-down". The bottom-up method is applied when nanostructures are assembled into an ordered structure as a result of chemical reactions. This method produces a hausmannite of a high purity, therefore it can be used in the fields that require a high precision (electrochemical processes, electrode materials, accumulators, capacitors, conductive materials, etc.). On the other hand Wang [6] recently presented a bottom-top method for hausmannite synthesis in mild conditions from aqueous solutions. Trimanganese tetraoxide nanoribbon was obtained from the manganese(II) acetate and the potassium hydroxide with the melamine-ethanol-distilled water by reflux and solvothermal methods [14]. The hausmannite nanoparticles were synthesized by mixing the egg white and the tetrahydrous $\mathrm{Mn}$ nitrate with intense stirring [19]. The $\mathrm{Mn}_{3} \mathrm{O}_{4}$ particles of nanograin forms, as well coinlike nanospheres, and nanoleaf structures were obtained, using co-precipitation, sol-gel, and hydrothermal processes [20]. The nanosized hausmannite particles were produced using an easy and steady process with ethylene deep eutectic solvent [21]. The nanosized particles of trimanganese tetraoxide were synthesized using ultrasound in various environment under mild conditions with no additional components [22]. The above-mentioned research aimed to synthesize manganese oxide nanoparticles of hausmannite under normal conditions in different media with ultrasonic waves. The process was conducted by applying ultrasound on the manganese(II) acetate in water media. Nanosized particles of high crystallinity with size no more than $4 \mathrm{~nm}$ were obtained on the 3rd minute of ultrasonic use [22]. However, Dhaouadi [23] invented synthesis of the $\mathrm{Mn}_{3} \mathrm{O}_{4}$ nanoparticles with novel morphology (lozange) under hydrothermal treatment, using surfactant cetyltetramethylammonium bromide (CTAB) as a templating agent. The obtained material was studied by X-ray diffraction (XRD), transmission electron microscopy (TEM), and impedance spectroscopy. The XRD analysis confirmed the formation of a single-phase in the tetragonal structure without any other impurities. From the results of XRD and TEM, the $\mathrm{Mn}_{3} \mathrm{O}_{4}$ nanoparticles show good morphology corresponding to nanosize between 40-70 nm [23]. The ultrafine $\mathrm{Mn}_{3} \mathrm{O}_{4}$ was obtained from the aqueous $\mathrm{MnSO}_{4}$ and ammonia under microwave irradiation [24]. In this research effects of the reaction temperature, $\mathrm{pH}$ value and the microwave irradiation time on the manganese content were investigated. Results showed that microwave heating could shorten the reaction time of conversion from the $\mathrm{Mn}(\mathrm{OH})_{2}$ to the $\mathrm{Mn}_{3} \mathrm{O}_{4}$ to $30 \mathrm{~min}$ at $80{ }^{\circ} \mathrm{C}$ and $\mathrm{pH}$ value of 10 , and the manganese content of trimanganese tetraoxide was $71.53 \%$. Specific surface area was $187 \mathrm{~m}^{2} \cdot \mathrm{g}^{-1} \mathrm{by}$ the Brunauer-Emmett-Teller method (BET). Particle size was in the range of 3-4 $\mu \mathrm{m}$ by scanning electron microscopy (SEM). The magnetic behavior of the sample was determined by Gouy magnetic balance. The calculated unpaired electrons of 4.41 was consistent with the theoretical value of 4.33 [24].

Above-mentioned methods are expensive and not simple technology-wise. Thus, the raw materials for above mentioned hausmannite synthesis methods are expensive chemical substances. However, the high pureness is not always necessary when using trimanganese tetraoxide as a colorant in the industry of building materials. Moreover, feedstock must be inexpensive and easily accessible. For that case, it is beneficial to develop methods of production the hausmannite from manganese ores. This production goes through the 
"top-down" method. The formation of nanostructures by the "top-down" route includes processing of macro-objects or structures for a successive decrease in their sizes, up to formation particles with nanometer sizes. This route of the $\mathrm{Mn}_{3} \mathrm{O}_{4}$ preparation is not common. Only a few research works presenting this way of preparation were published so far. For instance, $\mathrm{Lu}$ [25] used a "top-down" method to prepare the spongy $\mathrm{Mn}_{3} \mathrm{O}_{4}$. The above-mentioned research work aimed to produce the $\mathrm{Mn}_{3} \mathrm{O}_{4}$ with high surface area. During this research work effect of the different parameters, such as the heat-treatment temperature, the concentration of formic acid, and the solvothermal time on the morphology and crystallinity of the sample were investigated. The surface area of the samples was also investigated. The XRD was used to characterize the phase and crystallinity of the samples. The morphologies of the samples were investigated using a Hitachi S- 4800 field-emission scanning electron microscope (FE-SEM) with a cold field emitter. Energy-dispersive X-ray analysis (EDX) was carried out on a Hitachi S-4800. The TEM was used to observe the morphology and to investigate the crystallographic characteristics of the samples. The BET surface area was measured by a gas adsorption apparatus (AUTOSORB-1-C). The sponge-like $\mathrm{Mn}_{3} \mathrm{O}_{4}$ structures were prepared by decomposition of manganese formate at $200{ }^{\circ} \mathrm{C}$ via a facile "top-down" method. The sponge-like $\mathrm{Mn}_{3} \mathrm{O}_{4}$ structures were produced with a moderate concentration of formic acid with composed $\mathrm{Mn}_{3} \mathrm{O}_{4}$ nanocrystals about 20-30 nm and many pores. The morphology of the sponge-like $\mathrm{Mn}_{3} \mathrm{O}_{4}$ structures was mostly retained from the morphology of manganese formate precursors. The morphology of the sponge-like $\mathrm{Mn}_{3} \mathrm{O}_{4}$ structures was dependent on the solvothermal process before heat treatment. However, the sponge-like structures' internal microstructures depended on the heat treatment process [25]. In 1983 Koga [26] presented another "top-down" way of obtaining trimanganese tetraoxide. That study aimed to produce the battery-grade active manganese(IV) oxide by thermal decomposition of the manganese(IV) sulfate. The anhydrous manganese(II) sulfate was first decomposed at $1000{ }^{\circ} \mathrm{C}$ in the air to form trimanganese tetraoxide and then heated again at $700 \sim 800{ }^{\circ} \mathrm{C}$ in the air to obtain the manganese(III) oxide. The interfacial reaction was concluded to be the rate-determining step of the overall oxidation process. The remnant particles after extraction of the manganese(IV) sulfate from the manganese(IV) oxide with hot sulfuric acid was the $\gamma$-type manganese(IV) oxide. This oxide showed a high discharge activity equal to or superior to the electrolytic manganese(IV) oxide activity [26].

The most successful research work to produce hausmannite from manganese ore was conducted by Ratnawulan et al. [27]. In this scientific work researchers presented the method of preparation of the hausmannite from the manganese ore from the West Sumatra. Authors have obtained hausmannite by the high-energy milling method. The X-ray fluorescence (XRF) analysis results showed that the manganese content was $84.139 \%$. The hausmannite was produced when the sample was sintered at $700{ }^{\circ} \mathrm{C}$. The crystal structure of the hausmannite phase was tetragonal. The obtained hausmannite nanoparticles with homogeneous size distribution have been synthesized after $8 \mathrm{~h}$ of grinding time. The size of the nanoparticles produced was $90.50 \mathrm{~nm}$.

Recently Cheraghi [28] investigated the characterization and calcination behavior of low-grade manganese ore as a part of $\mathrm{Mn}$ ferroalloys production. Calcination experiments were carried out at up to $900^{\circ} \mathrm{C}$ in the air and argon atmospheres. The samples were in particles and powder forms. Thermal decomposition and reactive diffusion were found to be the dominant mechanisms in the calcination process. The results demonstrated that some phases were forming and vanishing during the calcination process in the air, such as calcium ferrites, calcium oxide, and bixbyite. While the Fe-containing bixbyite was thermally decomposed to hausmannite at low temperatures, magnetite was produced at higher temperatures. However, magnetite was also formed through the diffusion between hematite and hausmannite phases [28]. Therefore, one of the effective ways to obtain trimanganese tetraoxide as hausmannite phase is a thermal treatment of the manganesecontaining ores. 
The Republic of Kazakhstan has manganese-containing minerals suitable for trimanganese tetraoxide production such as deposits Bogach and Zhaksy. The Bogach deposit is placed in the Karaganda region (the Nura district), $180 \mathrm{~km}$ northeast of the Zhezkazgan city. It was discovered during regional geological works in 1983-1986 [29]. The Bogach deposit belongs to the Aidagarly syncline of the Sarysu-Teniz uplift. The length of the ore field is $2000 \mathrm{~m}$, width equals $1000 \mathrm{~m}$, and area is $2 \mathrm{~km}^{2}$. The upper horizon is ore-bearing composed of red-colored limestone, highly silicified in some places. Primary ores have a layered texture with frequent hematite, braunite, limestone, and jasper alternation in layers. Oxidized ores are featured by powdery-lumpy and earthy texture. Primary manganese ores usually contain braunite, hematite, ankerite, friedelite, jacobsite; among nonmetallic minerals calcite, quartz, chlorite, gypsum can be detected. The oxidized Mn ore includes minerals such as psilomelane, pyrolusite, hematite, vernadite, less often goethite, hollandite, jacobsite, braunite; quartz, kaolinite, mica, calcite, as well feldspars are included as nonmetallic mineral components. Elements such as $\mathrm{Rb}(0.002-0.004 \%), \mathrm{Cs}(0.002 \%)$, $\mathrm{Tl}(2.56 \mathrm{~g} / \mathrm{t}), \mathrm{Ge}(<3 \mathrm{~g} / \mathrm{t})$, As $(0.005-0.007 \%)$ can be detected in both types of ore as impurities. Impurities such as $\mathrm{Co}, \mathrm{Sr}$, and Mo are mentioned in other mineral catalogues [30]. Over the 10-year period, it was processed about 430,200 tons of commercial ore.

The Zhaksy deposit of Mn ore is placed in the Akmola region of Kazakhstan (Zhaksy district). The Zhaksy deposit belongs to the southwestern segment of the Kalmakkul synclinorium. The Lower Ordovician red clayed-siliceous shales include multiple layers of thin ore. The deposit includes different Mn-containing minerals: psilomelane, braunite, hausmannite, and pyrolusite. Among nonmetallic minerals calcite, quartz, chlorite, chalcedony, as well sericite is detected. Pyrite and chalcopyrite are sometimes detected as impurities. The degree of mineralization of inclusions to complete replacement of rock with ore minerals [30].

These deposits were not widely described in scientific literature before. There is no information about phase, elemental content, and there is no microphotograph of the ores from deposits Zhaksy and Bogach. However, that information is necessary to study the possibility of application of "top-down" method for trimanganese tetraoxide production from manganese ores of Zhaksy and Bogach deposits.

The purpose of the research is to study the structure and content of manganese ores from Bogach and Zhaksy deposits using state-of-the-art SEM, EDA, XRD, IR-Fourier spectral analysis methods. Based on the results of the proposed study, an assumption of possible application of these ores as a raw material for commercial production of trimanganese tetraoxide in the hausmannite phase will be given. Thus, the object of the research is manganese ores from Bogach and Zhaksy deposits placed in Kazakhstan.

\section{Materials and Methods}

2.1. Samples

Two samples of raw materials were prepared for the proposed study:

(1) ore of the Bogach deposit (Kazakhstan) (sample 1);

(2) ore of the Zhaksy deposit (Kazakhstan) (sample 2);

Samples of manganese ore from the Bogach and Zhaksy deposits were broken rock fragments (lumpy form). The initial appearance is shown in Figure 1.

The initial crushing to 1-5 mm granules was carried out on a jaw crusher "DSh $100 \times 200$ " (Russia). Further grinding was performed for $8 \mathrm{~h}$ on a laboratory ball mill "MShL-1" (Russia).

Figure 2 shows that the ore sample from the Bogach deposit is almost black shade, darker than from the Zhaksy deposit. This feature is a consequence of the higher concentration of manganese in the ore composition. 


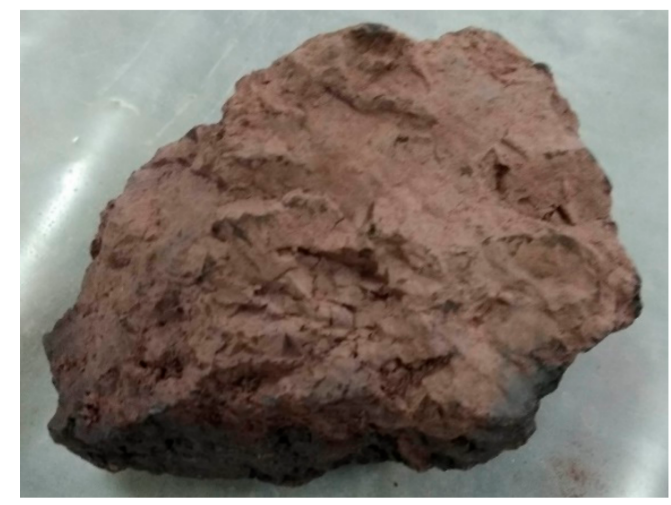

Figure 1. Sample of manganese ore rock from the Zhaksy deposit.

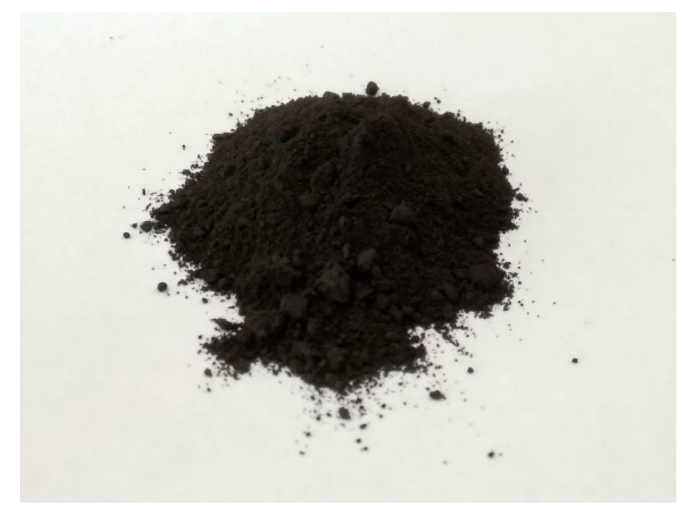

(a)

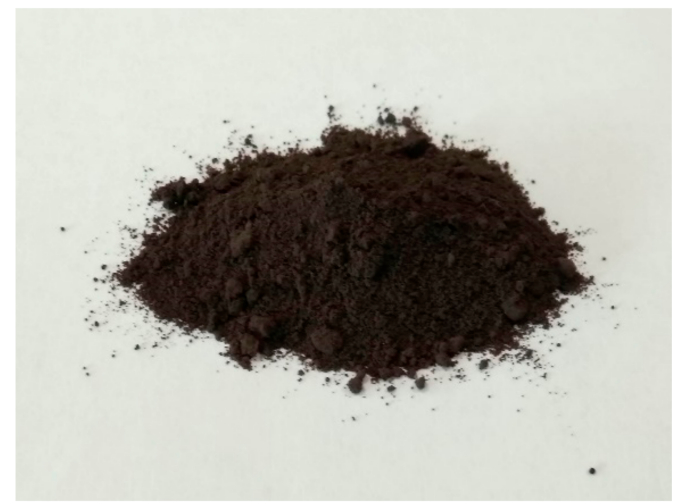

(b)

Figure 2. Samples of raw materials: (a) manganese ore from the Bogach deposit; (b) manganese ore from the Zhaksy deposit.

\subsection{Methods}

The study by electronic microscopy was conducted at the Engineering Laboratory of the Eurasian National University named after L.N. Gumilyov (Almaty, Kazakhstan) on a Hitachi TM3030 scanning electron microscope with a Bruker "XFlash MIN SVE" microanalysis system at an average voltage of $15 \mathrm{kV}$. Elemental analysis was carried out using energy-dispersive analysis (EDA) by taking at least 7 spectra from each sample to obtain an average normalized value. The data on the content of elements are given in weight percent.

$X$-ray diffractometric $(\mathrm{XRD})$ analysis was carried out on an automatic diffractometer "DRON-3" with CuKa radiation, $\beta$-filter. The analysis was carried out at $\mathrm{U}=35 \mathrm{kV}$, $\mathrm{I}=20 \mathrm{~mA}$, shooting $\theta-2 \theta$, detector $2 \mathrm{deg} / \mathrm{min}$. XRD phase analysis on the semi-quantitative basis has been carried out by diffractograms of powder samples using the method of equal samples and artificial mixtures. Quantitative correlations of crystal phases have been determined. Interpretation of diffractograms has been carried out using the catalogue of the International Centre for Diffraction Data, the database of powder diffractometric data PDF2 (Powder Diffraction File) and diffractograms of pure minerals.

IR spectra were obtained on IR-Fourier spectrometer "TENSOR R27" (Bruker). Parameters of the analysis: detector DLATGS, IR range of the spectrum $4000-400 \mathrm{~cm}^{-1}$, data accumulation mode-absorbance, resolution $4 \mathrm{~cm}^{-1}$, gain-4.0, mirror speed-0.6329, source-IR in the middle range, aperture-iris $6 \mathrm{~mm}$, beam splitter- $\mathrm{KBr}$, transformationFourier, temperature $21^{\circ} \mathrm{C}$. 


\section{Results and Discussions}

3.1. Electron Microscopy with EDA

Figures 3 and 4 show micrographs of the investigated samples at resolutions $\times 100$, $\times 300, \times 1000, \times 3000$.
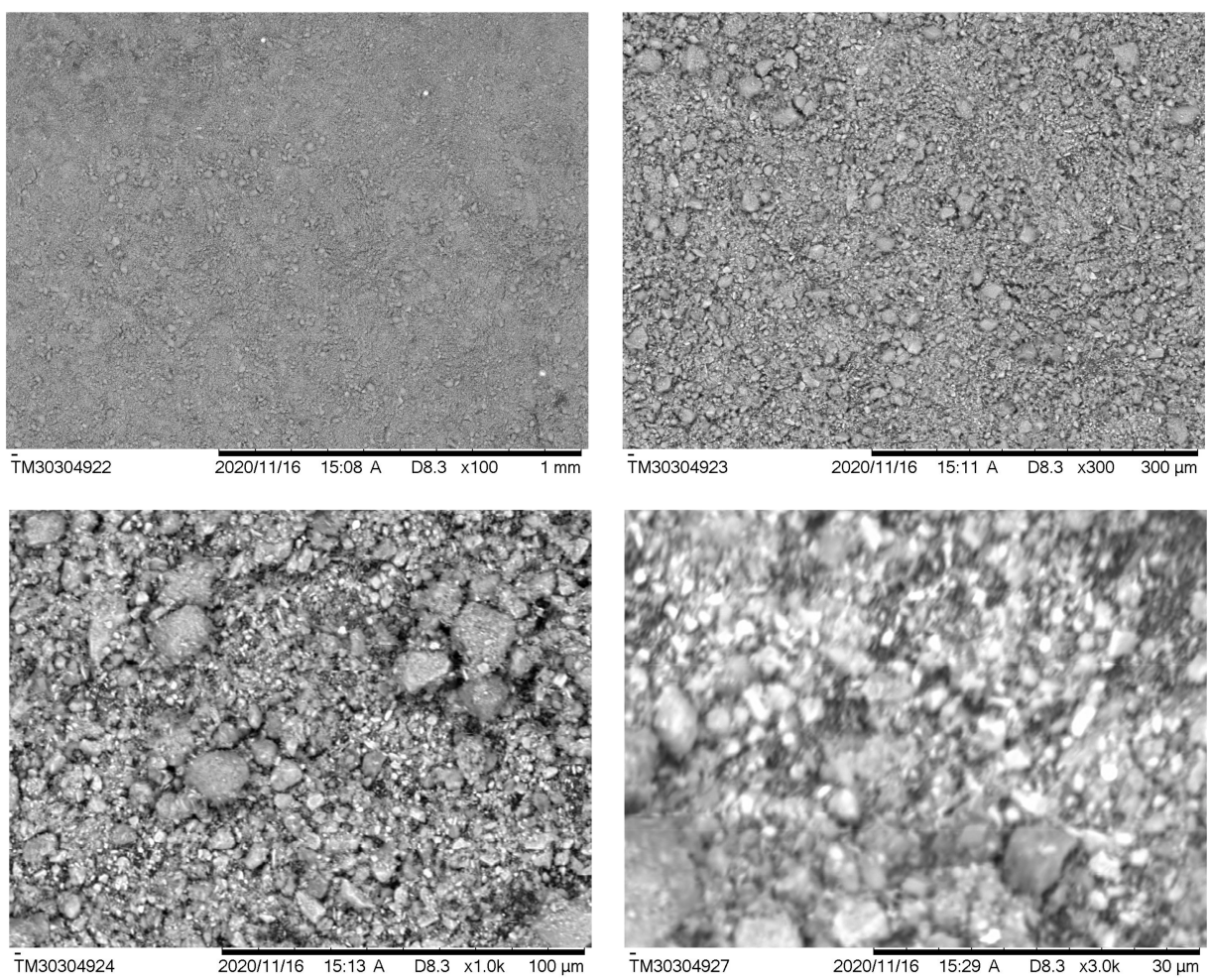

Figure 3. Electronic micrographs of the samples of manganese ore from the Bogach deposit.
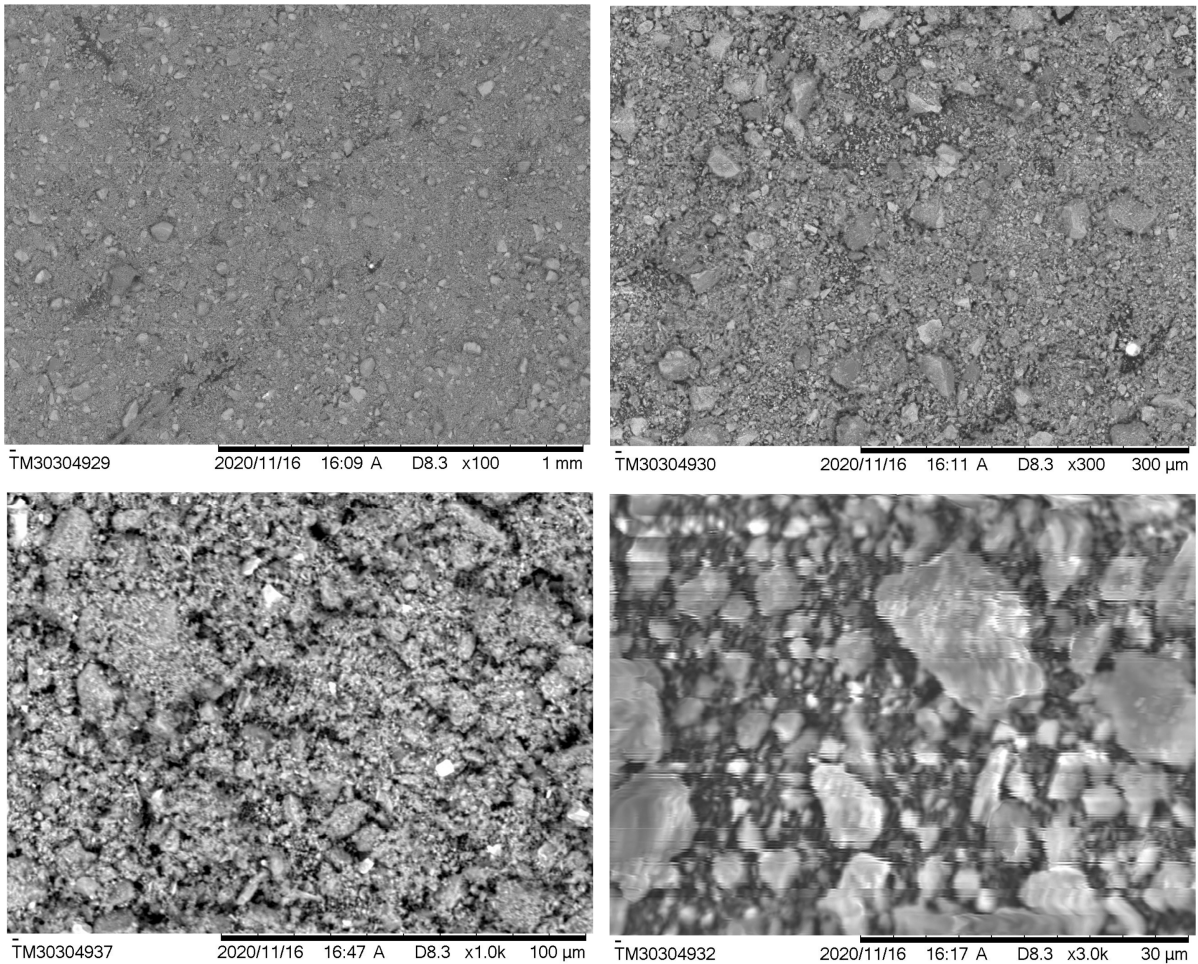

Figure 4. Electronic micrographs of the samples of manganese ore from the Zhaksy deposit. 
The analysis of micrographs reveals that the dispersive capacity of samples No. 1 and 2 are similar to each other and ranges from one to several tens of microns.

The microanalysis system made it possible to analyze the elemental composition of the samples by the energy-dispersive analysis method. Figure 5 shows a typical spectrogram of the sample. Tables 1 and 2 present the findings of the elemental analysis of the investigated samples.

According to the elemental analysis data, it is seen that the ore of the Bogach deposit contains two times more manganese than the Zhaksy deposit, with a content of $43.26 \%$ on average. At the same, the iron is absent in the Bogach ore. Content of Fe in Zhaksy ore is not significant, about $5 \%$ on average. Table 3 presents normalized distributions of the atomic composition (at.\%) in the investigated samples.

Figures 6 and 7 present the micrographs with mapping of the distribution of elements on the focused surface of the sample. In all samples, there are inclusions of dense crystallites containing silicon. These formations may belong to waste rock particles.

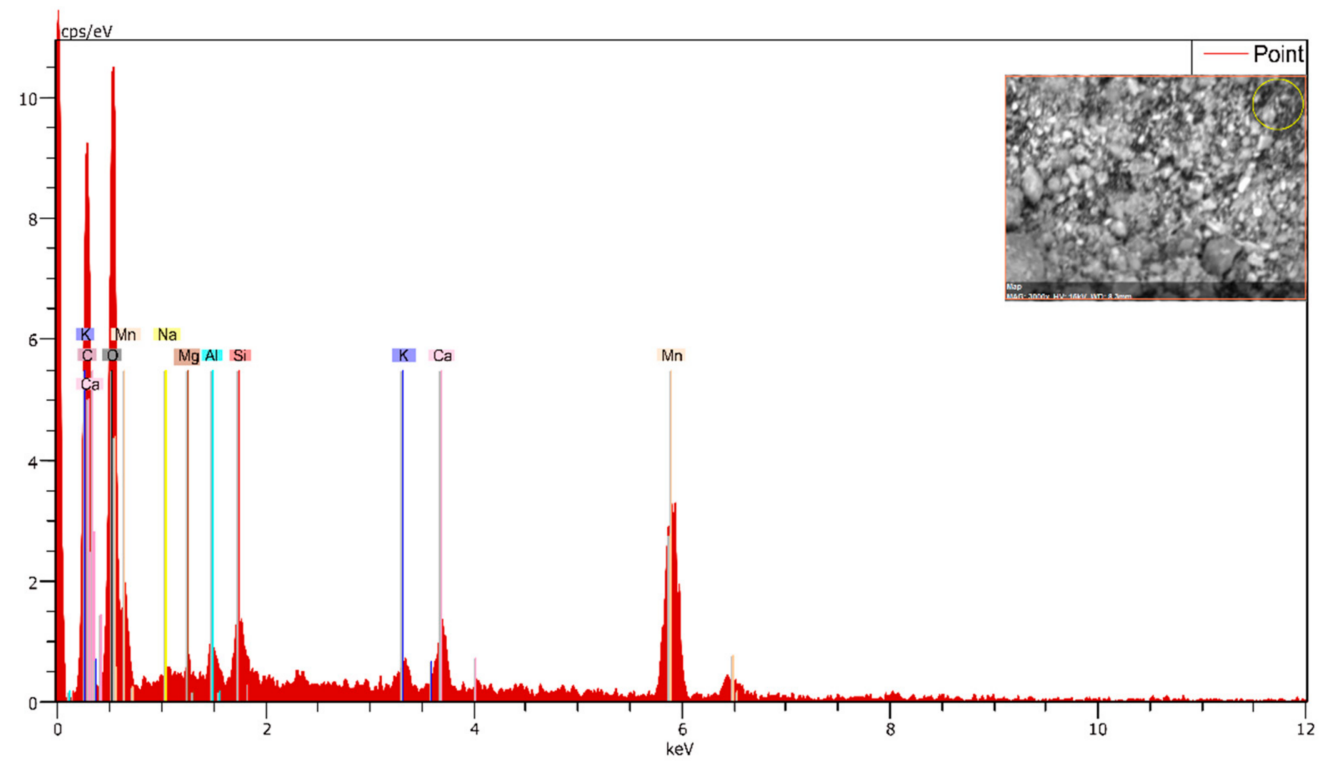

Figure 5. The spectrogram of the sample of manganese ore from the Bogach deposit.

Table 1. Findings of the elemental analysis of Mn ore samples of the Bogach.

\begin{tabular}{|c|c|c|c|c|c|c|c|c|c|c|c|c|}
\hline \multirow{2}{*}{ Point } & \multicolumn{11}{|c|}{ Elemental Content, wt. $\%$} & \multirow{2}{*}{ Tota } \\
\hline & $\mathrm{C}$ & $\mathrm{O}$ & Mn & $\mathrm{Ca}$ & Si & $\mathrm{Na}$ & Al & Mg & $\mathbf{K}$ & $\mathrm{Fe}$ & $\mathrm{Cu}$ & \\
\hline 1 & 36.2 & 40.04 & 17.75 & 2.13 & 1.26 & 0.67 & 0.69 & 0.52 & 0.73 & 0 & 0 & 100 \\
\hline 2 & 10.75 & 33.55 & 40.56 & 4.78 & 6.53 & 0 & 0.98 & 0.99 & 1.87 & 0 & 0 & 100 \\
\hline 3 & 5.54 & 32.55 & 47.21 & 7.18 & 3.26 & 0.28 & 0.95 & 0.98 & 2.05 & 0 & 0 & 100 \\
\hline 4 & 7.57 & 36.48 & 36.34 & 6.54 & 6.56 & 1.71 & 2.38 & 0.9 & 1.53 & 0 & 0 & 100 \\
\hline 5 & 3.5 & 25.36 & 51.63 & 11.28 & 4.78 & 0.09 & 1.22 & 0.35 & 1.79 & 0 & 0 & 100 \\
\hline 6 & 5.55 & 29.03 & 50.58 & 9.41 & 2.01 & 0.79 & 0.94 & 0.18 & 1.51 & 0 & 0 & 100 \\
\hline 7 & 3.11 & 16.76 & 68.48 & 4.13 & 1.39 & 0.16 & 1.46 & 0.48 & 4.03 & 0 & 0 & 100 \\
\hline 8 & 13.21 & 42.22 & 33.56 & 5.47 & 2.27 & 0.43 & 0.44 & 1.09 & 1.31 & 0 & 0 & 100 \\
\hline average & 10.68 & 32 & 43.26 & 6.36 & 3.51 & 0.52 & 1.13 & 0.69 & 1.85 & 0 & 0 & 100 \\
\hline
\end{tabular}


Table 2. Findings of the elemental analysis of Mn ore samples of the Zhaksy.

\begin{tabular}{|c|c|c|c|c|c|c|c|c|c|c|c|c|}
\hline \multirow{2}{*}{ Point } & \multicolumn{11}{|c|}{ Elemental Content, wt.\% } & \multirow{2}{*}{ Tota } \\
\hline & $\mathrm{C}$ & $\mathbf{O}$ & Mn & $\mathrm{Ca}$ & Si & $\mathrm{Na}$ & Al & Mg & $\mathbf{K}$ & $\mathrm{Fe}$ & $\mathrm{Cu}$ & \\
\hline 1 & 42.38 & 41.72 & 7.58 & 0 & 4.92 & 0 & 1.23 & 0 & 0.32 & 1.85 & 0 & 100 \\
\hline 2 & 22.86 & 47.48 & 7.99 & 0 & 16.93 & 0 & 1.52 & 0 & 0.39 & 2.84 & 0 & 100 \\
\hline 3 & 3.87 & 5.14 & 58.14 & 0 & 8.85 & 0 & 8.79 & 0 & 3.48 & 11.73 & 0 & 100 \\
\hline 4 & 40.37 & 37.11 & 11.39 & 0 & 5.55 & 0 & 1.74 & 0 & 0.59 & 3.25 & 0 & 100 \\
\hline 5 & 36.4 & 45.09 & 7.94 & 0 & 6.46 & 0 & 1.54 & 0 & 0.29 & 2.28 & 0 & 100 \\
\hline 6 & 18.5 & 41.75 & 22.32 & 0 & 9.41 & 0 & 3.29 & 0 & 1.03 & 3.7 & 0 & 100 \\
\hline 7 & 2.02 & 6.38 & 37.33 & 0 & 21.49 & 0 & 17.8 & 0 & 2.35 & 12.63 & 0 & 100 \\
\hline average & 23.77 & 32.1 & 21.81 & 0 & 10.52 & 0 & 5.13 & 0 & 1.21 & 5.47 & 0 & 100 \\
\hline
\end{tabular}

Table 3. Normalized distribution of the content of atoms of elements (at.\%).

\begin{tabular}{|c|c|c|c|c|c|c|c|c|c|c|c|c|}
\hline \multirow{2}{*}{ Sample } & \multicolumn{11}{|c|}{ Elemental Content, at.\% } & \multirow{2}{*}{ Total } \\
\hline & $\mathrm{C}$ & $\mathbf{O}$ & Mn & $\mathrm{Ca}$ & $\mathrm{Si}$ & $\mathrm{Na}$ & Al & $\mathrm{Mg}$ & $\mathbf{K}$ & $\mathrm{Fe}$ & $\mathrm{Cu}$ & \\
\hline Bogach & 10.5 & 33.7 & 44.4 & 4.9 & 3.3 & 0.0 & 0.7 & 0.6 & 2.0 & - & - & 100 \\
\hline Zhaksy & 12.2 & 12.2 & 40.1 & - & 11.9 & - & 12.3 & - & 3.4 & 8.0 & - & 100 \\
\hline
\end{tabular}
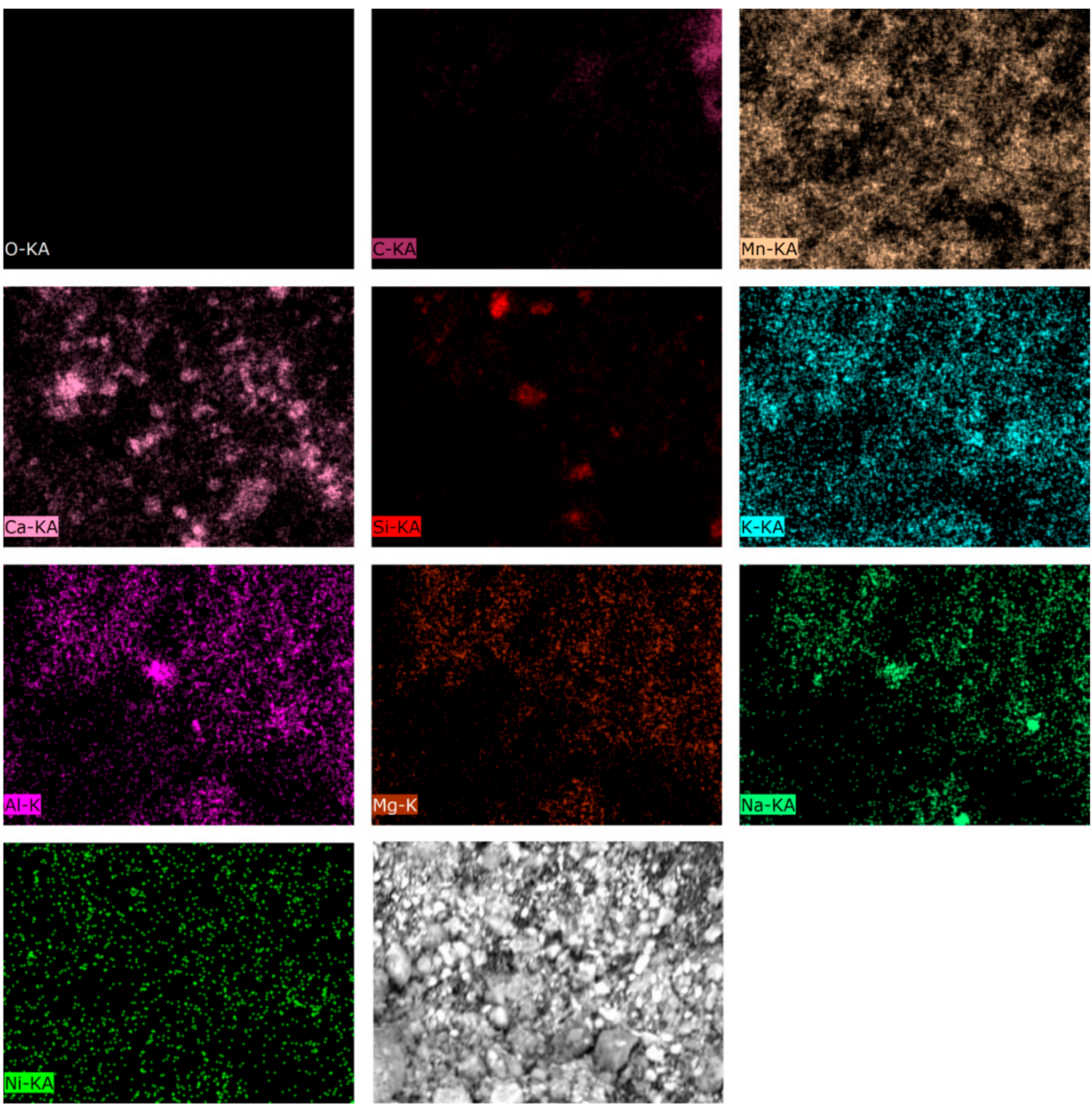

Figure 6. Micrographs with mapping of the distribution of elements on the focused surface of the manganese ore sample from the Bogach deposit. 

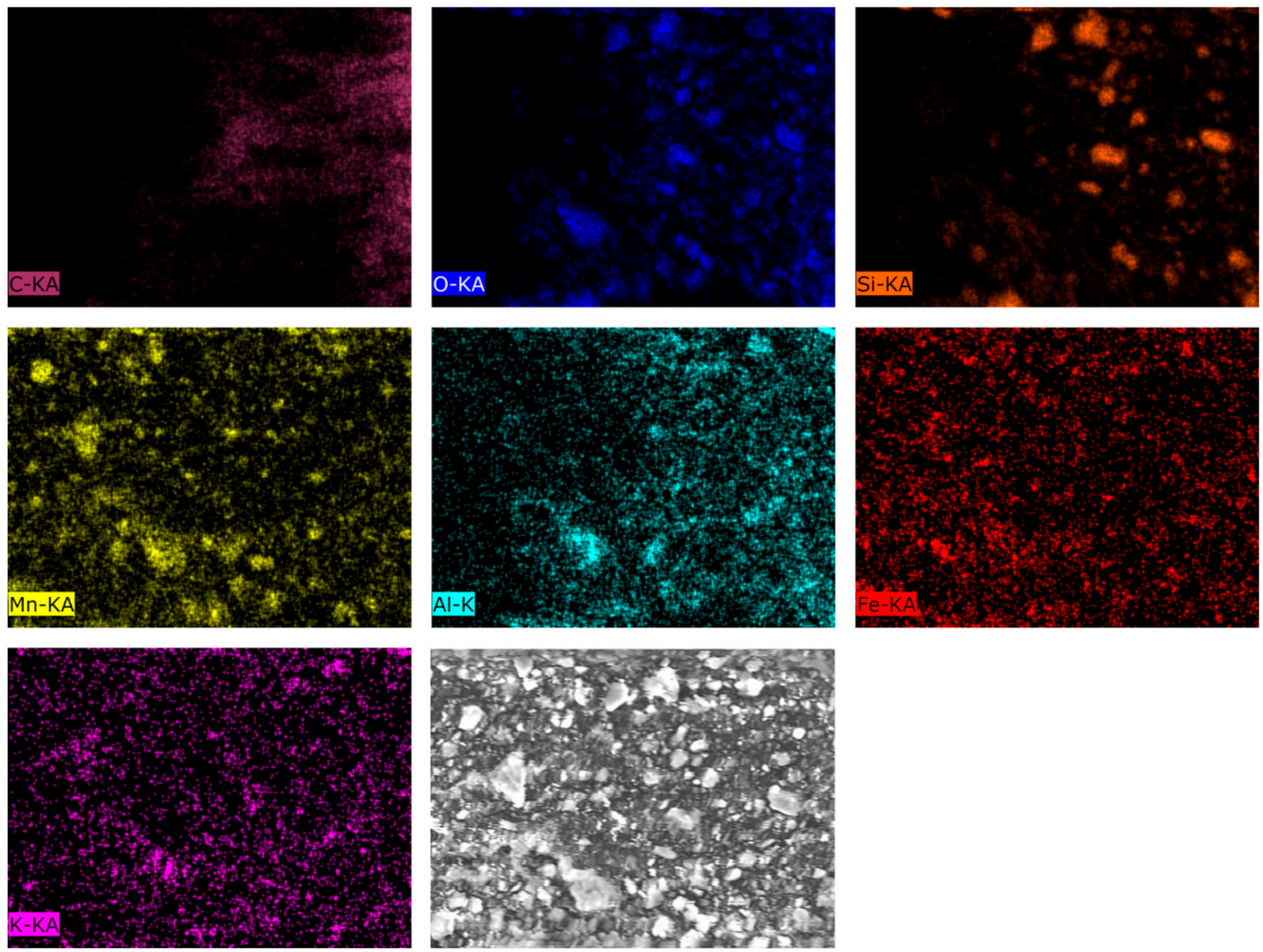

Figure 7. Micrographs with mapping of the distribution of elements on the focused surface of the manganese ore sample from the Zhaksy deposit.

In all micrographs, these formations look similar to dense monolithic particles with a size of 20-30 microns. In all samples, manganese gives a quite dense background, which indicates a sufficiently high or average content of it in the composition of the raw ore.

The analysis of the obtained micrographs of the samples under study revealed that the dispersive capacity of ore samples from the Bogach deposit (sample 1) and Zhaksy deposit (sample 2) is similar to each other and ranges from one to several tens of microns.

Micrographs with mapping of the distribution of elements on the focused surface of the sample provide the opportunity to study highly-relief surfaces and obtain information about the state of the surface layer and adjust the image of sub-layers.

Thus, in both investigated samples, there are inclusions of dense crystallites containing silicon as the main rock-forming component representing dense monolithic conglomerates with a size of 20-30 microns. It should be highlighted that manganese in all samples gives a quite dense background that corresponds to a high or average Mn content in the raw ore composition. In particular cases, it depends on the source of origin, sample preparation, degree of grinding, moisture content, etc.

Based on the obtained elemental analysis data, it was found that in terms of manganese content, the ore of the Bogach deposit contains about $43.06 \mathrm{wt} . \%$ while the iron content in the same ore is reduced to zero. The lower content of manganese mineral is found in the poor oxidized ore of Zhaksy deposit, which comprises about $22.00 \mathrm{wt}$. \% due to the presence and influence of silicates, alumina, lime, and magnesia, and its mineralogical features, it is represented by oxide forms of manganese and iron (5.47 wt.\%) and, as a result, has a dark brown color. 


\subsection{X-ray Diffractometry Analysis}

XRD analysis was used for the investigation phase content of the studied samples. Values of interplanar distances, relative intensities of reflexes, and semi-quantitative content of crystal phases were obtained. The results of mineralogical analyses of the studied samples are shown in Tables 4 and 5. It was observed that all listed diffraction peaks belong to phases specified in the tables. Characteristic diffraction reflexes allowing identification of present phases are registered in all samples.

Table 4. Interplanar distances, relative intensities of reflexes, and phase content of manganese ore sample from the Bogach deposit.

\begin{tabular}{ccc}
\hline $\mathbf{d}, \mathbf{A}$ & $\mathbf{I}, \boldsymbol{\%}$ & Mineral \\
\hline 6.95 & 92.5 & hollandite, cryptomelane \\
4.91 & 72.4 & hollandite, cryptomelane \\
3.34 & 81.7 & quartz \\
3.11 & 87.8 & hollandite, cryptomelane \\
3.03 & 83.6 & calcite \\
2.71 & 100.0 & bixbyite, braunite \\
2.40 & 82.3 & hollandite, cryptomelane \\
2.16 & 65.7 & hollandite, cryptomelane \\
1.83 & 63.9 & hollandite, cryptomelane \\
1.66 & 63.9 & bixbyite, braunite \\
\hline
\end{tabular}

Table 5. Interplanar distances, relative intensities of reflexes, and phase content of manganese ore sample from the Zhaksy deposit.

\begin{tabular}{ccc}
\hline $\mathbf{d}, \AA$ & $\mathbf{I}, \boldsymbol{\%}$ & Mineral \\
\hline 4.26 & 30.5 & quartz \\
3.34 & 100.0 & quartz \\
3.11 & 21.5 & hollandite, pyrolusite \\
2.71 & 46.5 & bixbyite \\
2.52 & 22.7 & bixbyite \\
2.46 & 20.1 & quartz \\
2.40 & 23.5 & hollandite, pyrolusite \\
2.35 & 20.2 & bixbyite \\
2.28 & 20.5 & quartz \\
2.24 & 19.1 & quartz \\
1.82 & 25.7 & quartz \\
1.66 & 20.7 & quartz, bixbyite \\
\hline
\end{tabular}

Tables 6 and 7 show the concentration distribution of different mineral phases present in studied samples. Mn-containing phases are mainly hollandite, cryptomelane, braunite, bixbyite, pyrolusite.

Table 6. Results of semantical XRD analysis of crystalline phases of manganese ore sample from the Bogach deposit.

\begin{tabular}{ccc}
\hline Mineral & Formula & Concentration, \% \\
\hline hollandite & $\mathrm{Mn}_{6.95} \mathrm{Fe}_{0.64} \mathrm{Al}_{0.26} \mathrm{Si}_{0.02} \mathrm{Ba}_{0.47} \mathrm{~K}_{0.33} \mathrm{~Pb}_{0.11} \mathrm{Na}_{0.11} \mathrm{O}_{16} \mathrm{H}_{1.41}$ & 37.4 \\
cryptomelane & $\left(\mathrm{K}_{1.3} \mathrm{Na}_{0.22} \mathrm{Sr}_{0.16}\right)\left(\mathrm{Mn}_{0.9475} \mathrm{Fe}_{0.0375} \mathrm{Al}_{0.025}\right)_{8} \mathrm{O}_{16}$ & 33.2 \\
braunite & $\mathrm{CaMnn}_{11.62} \mathrm{Fe}_{2.38} \mathrm{SiO}_{24}$ & 10.4 \\
calcite & $\mathrm{Ca}_{\left(\mathrm{CO}_{3}\right)}$ & 8.4 \\
bixbyite & $\mathrm{Mn}_{2} \mathrm{O}_{3}$ & 6.4 \\
quartz & $\mathrm{SiO}_{2}$ & 4.3 \\
\hline
\end{tabular}


Table 7. Results of semantical XRD analysis of crystalline phases of manganese ore sample from the Zhaksy deposit.

\begin{tabular}{ccc}
\hline Mineral & Formula & Concentration, \% \\
\hline quartz & $\mathrm{SiO}_{2}$ & 45.5 \\
hollandite & $\mathrm{Mn}_{6.95} \mathrm{Fe}_{0.64} \mathrm{Al}_{0.26} \mathrm{Si}_{0.02} \mathrm{Ba}_{0.47} \mathrm{~K}_{0.33} \mathrm{~Pb}_{0.11} \mathrm{Na}_{0.11} \mathrm{O}_{16} \mathrm{H}_{1.41}$ & 25.1 \\
bixbyite & $\mathrm{Mn}_{2} \mathrm{O}_{3}$ & 20.5 \\
pyrolusite & $\mathrm{MnO}_{2}$ & 8.9 \\
\hline
\end{tabular}

By total content of Mn-containing phases, the samples are placed in the following row: sample 1 (Bogach) - $87.4 \%$, sample 2 (Zhaksy) - 54.5\%. However, the content of Mn must be taken into account as an element in the structure of the Mn-containing phase. Manganese ore from Zhaksy contains the maximal percentage of empty rock as quartz.

Figures 8 and 9 show diffractograms of the samples. It can be seen from the figures that the sample of Bogach ore is more amorphous in comparison with the Zhaksy sample. In these samples, the diffusivity of the reflexes indicates a not high degree of crystallinity of the mineral structure. All samples, excluding Zhaksy, background points on Mn's significant content, confirmed with elemental analysis.

\subsection{IR-Spectrometry Analysis}

IRS methods allow obtaining information about the presence of minerals in ores by wavenumbers. Thus, pyrolusite is characterized by wave numbers 610 and $830 \mathrm{~cm}^{-1}$, manganite-550, 610 and $1100 \mathrm{~cm}^{-1}$, psilomelane-550, 830 and $1050 \mathrm{~cm}^{-1}$ (Table 8) [31].

The IR spectra of samples of manganese ores differ not only in the presence of ore minerals of manganese but also in the peaks corresponding to the phosphate group $\mathrm{PO}_{4}{ }^{3-}$. That is confirmed by correspondence of calcium triphosphate wave numbers to wave numbers of phosphate group in manganese ore spectra or fluctuations of the phosphorusoxygen group 1090-1050 $\mathrm{cm}^{-1}$ [31].

Due to the different intensity of the obtained characteristic absorption bands (Figures 10 and 11) in the mid-IR range, two sub-wavelength ranges are conditionally distinguished: high-frequency range No.1-4000-1700 $\mathrm{cm}^{-1}$ and low-frequency range No.2-1700-400 $\mathrm{cm}^{-1}$. The obtained data are presented in a graphical dependence of the absorbance units $(\%)$ on the wavenumber $\left(\mathrm{cm}^{-1}\right)$.

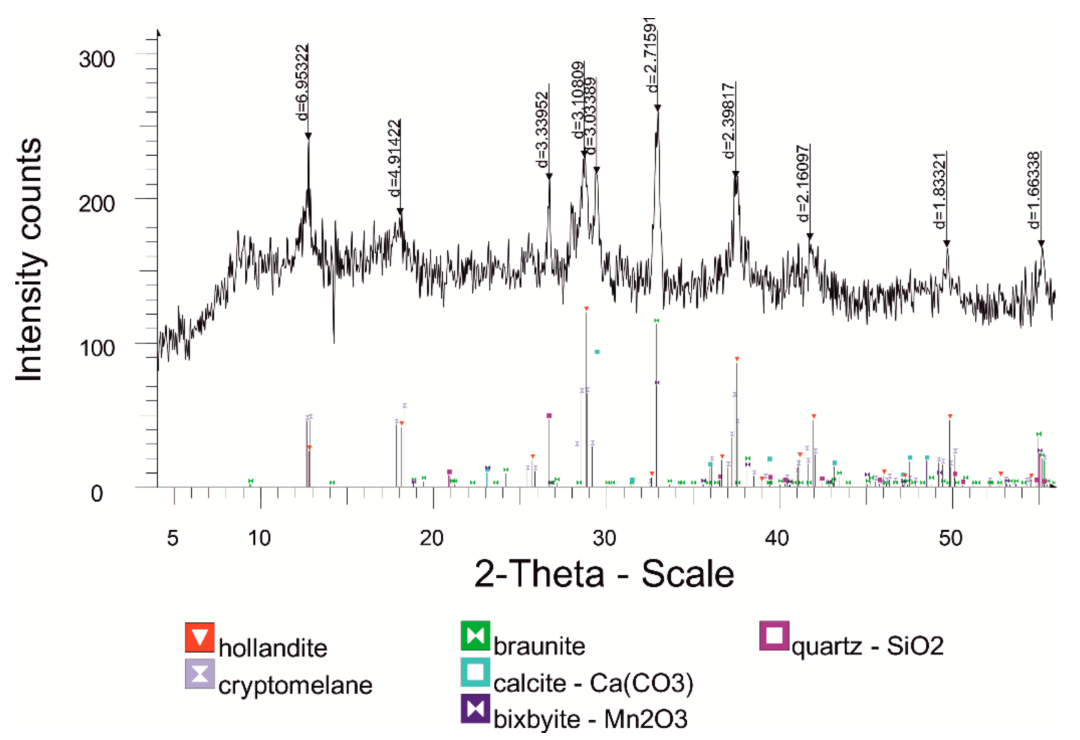

Figure 8. Diffractogram of manganese ore sample from the Bogach deposit. 


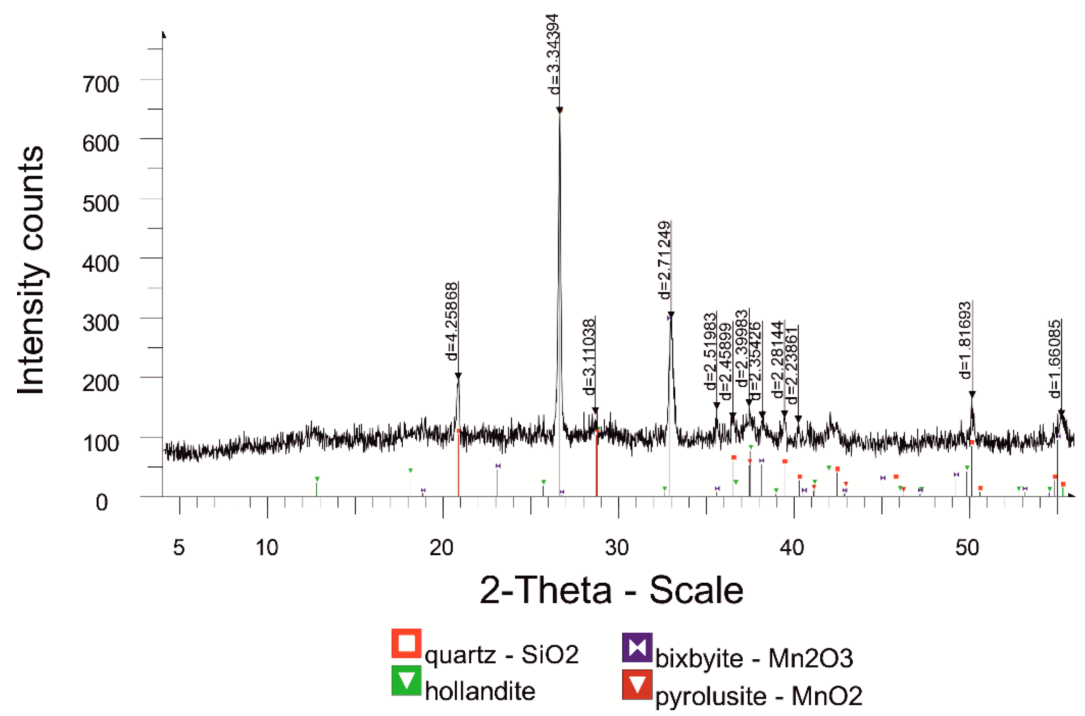

Figure 9. Diffractogram of manganese ore sample from the Zhaksy deposit.

Table 8. Infrared radiation absorption values of manganese monomineral fractions, oxide and carbonate manganese ores determined by IR spectroscopy [31].

\begin{tabular}{|c|c|c|c|c|c|}
\hline \multirow[t]{3}{*}{$\begin{array}{c}\text { Name of Manganese Minerals and } \\
\text { Oxide Ore }\end{array}$} & \multicolumn{5}{|c|}{$\begin{array}{l}\text { The Values of the Infrared Radiation Absorption in the Corresponding Wavenumber } \\
\text { Intervals, } \mathrm{cm}^{-1}\end{array}$} \\
\hline & $450-620$ & $725-830$ & $1050-1150$ & $1420-1470$ & 1630 \\
\hline & \multicolumn{2}{|c|}{$(\mathrm{Mn}-\mathrm{O}, \mathrm{Ca}-\mathrm{O})$} & $(\mathrm{P}-\mathrm{O})$ & $\mathrm{CO}_{3}^{2-}$ & $\mathrm{OH}$ \\
\hline psilomelane & 70 & 23 & 47 & - & - \\
\hline manganite $\mathrm{y}-\mathrm{MnOOH}$ & 62 & - & 58 & - & - \\
\hline pyrolusite (reactive) & 92 & - & - & - & - \\
\hline psilomelane ore & 70 & - & 49 & 42 & 46 \\
\hline pyrolusite ore & 72 & - & 46 & 57 & - \\
\hline manganese ore & 68 & - & 51 & - & - \\
\hline oxide ore (oxidized) & 106 & - & 100 & - & 34 \\
\hline oxide ore (top layer of the formation) & 74 & - & 62 & 60 & - \\
\hline $\begin{array}{l}\text { tricalcium phosphate } \\
\text { (preparation) } \mathrm{Ca}_{3} \mathrm{P}_{2} \mathrm{O}_{8}\end{array}$ & 55 & - & 76 & - & - \\
\hline manganocalcite $(\mathrm{Mn}, \mathrm{Ca}) \mathrm{CO}_{3}$ & 24 & $19-27$ & 60 & 73 & - \\
\hline carbonate manganese ore & 27 & 36 & 58 & 71 & - \\
\hline
\end{tabular}

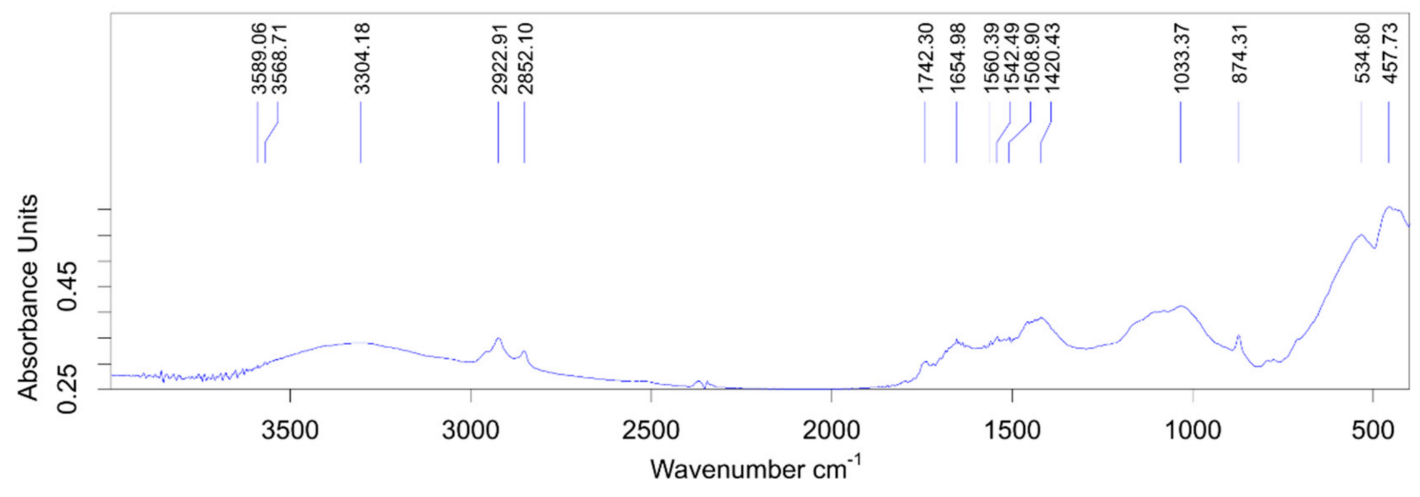

Figure 10. The infrared absorption spectrum of manganese ore from the Bogach deposit. 


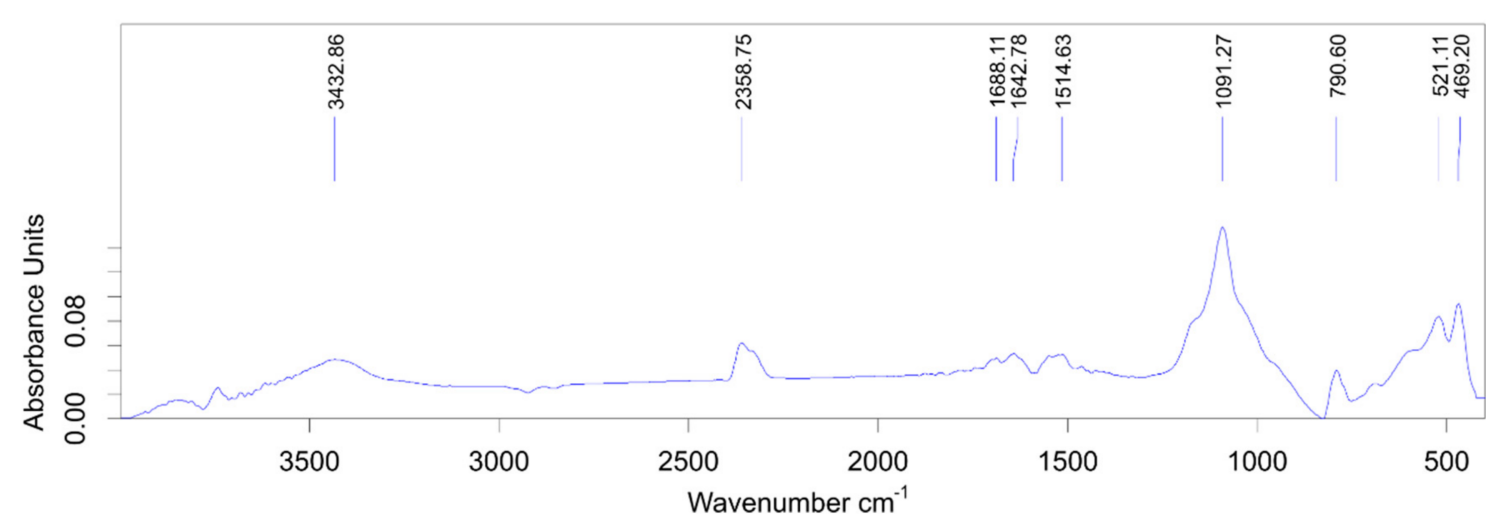

Figure 11. The infrared absorption spectrum of manganese ore from the Zhaksy deposit.

The IR spectra of manganese hydroxides, depending on their degree of crystallinity, are represented either by single broadband or by clear bands in the range from 425 to $530 \mathrm{~cm}^{-1}$ due to the $\mathrm{Mn}-\mathrm{O}$ bonds in the octahedron $\left[\mathrm{Mn}^{4+} \mathrm{O}_{6}\right]$, as well as in the region from 3100 to $3500 \mathrm{~cm}^{-1}$ by the valence vibrations of $\mathrm{OH}$ bonds [32,33]. The spectra of the studied samples are represented by complex broad bands that are practically not split into separate maxima. It is quite difficult to quantify the ratio of various manganese minerals according to infrared spectroscopy data. Diffractograms record the most well-crystallized phases, IR spectra characterize the sample in the near-order region and register both crystalline and amorphous components.

In the high-frequency IR range No.1, there are characteristic bands of sorbed and crystallized water molecules: $3431-2900 \mathrm{~cm}^{-1}, 2360-2350 \mathrm{~cm}^{-1}$-intra- and intermolecular valence vibrations, and $1660-1640 \mathrm{~cm}^{-1}$ - deformation vibrations of hydroxyl $-\mathrm{OH}$ groups [34]. The shift of the valence band $-\mathrm{OH}$ to $3400 \mathrm{~cm}^{-1}$ is associated with the predominance of a weaker degree of hydrogen bonding in the water structure [35]. The appearance of low-intensity bands in the region of $2800 \mathrm{~cm}^{-1}$ is also caused by oxidation processes [36].

The samples of Kazakhstan origin are well moisture-saturated. The greater presence of oxide compounds was recorded in samples since they belong to oxidized manganese ores.

Identification of the low-frequency range No.2 is difficult due to a significant number of characteristic bands of manganate, phosphate, carbonate, silicate, and sulfate groups (less often, wolframite groups). Their superposition and abnormal displacement are due, firstly, to their mutual influence and, secondly, to the presence of manganese minerals, which are directly proportional to the quantitative content.

In oxidized ores, as a rule, the carbonate groups have a fairly clear range of characteristic absorption bands in the range of $1470-1420 \mathrm{~cm}^{-1}$ [31]. A fairly clear picture of the IR spectrum is observed for the sample of the Bogach deposit (Figure 10), wherein the region of $1508-1420 \mathrm{~cm}^{-1}$, there is a band of medium intensity corresponding to manganocalcite and rhodochrosite.

An equally intense band of orthophosphoric and phosphate groups is identified in the middle region of range No.2 and corresponds to the value of $1033 \mathrm{~cm}^{-1}$. The revealed patterns are in good agreement with the results of the X-ray phase analysis.

A detailed study of the sample from the Zhaksy deposit shows a slightly different picture. Figure 11 shows the areas of deformation vibrations of carbonate groups, but their content is negligible. The presence of a pronounced peak with high intensity at a wavelength of $1090 \mathrm{~cm}^{-1}$ is also identified as valence vibrations of the carbonate groups of the manganese mineral-pyrolusite.

This pattern is also due to the presence of a large amount of quartz and manganese silicates: braunites, rhodonites, and manganese-containing garnets. It is necessary to consider that the content of iron, its oxide, and silicate forms is maximum for Zhaksy manganese ore. 
The first half of the low-frequency range No. $2\left(800-400 \mathrm{~cm}^{-1}\right)$ is most characteristic of the deformation vibrations of the same salts and the metal-oxygen valence vibrations in the crystal basis of oxides, including $\mathrm{Mn}_{\mathrm{x}} \mathrm{O}_{\mathrm{y}}$ [37].

The most common manganese dioxide $(+4)$ corresponds to a peak in the region of $560 \mathrm{~cm}^{-1}$ [38]. In studied manganese ores, it is also present in its less oxidized form (oxidation state +2 and +3 ) -hausmannite $\left(536-521 \mathrm{~cm}^{-1}\right.$ ), psilomelane, and manganite (Figure 12).

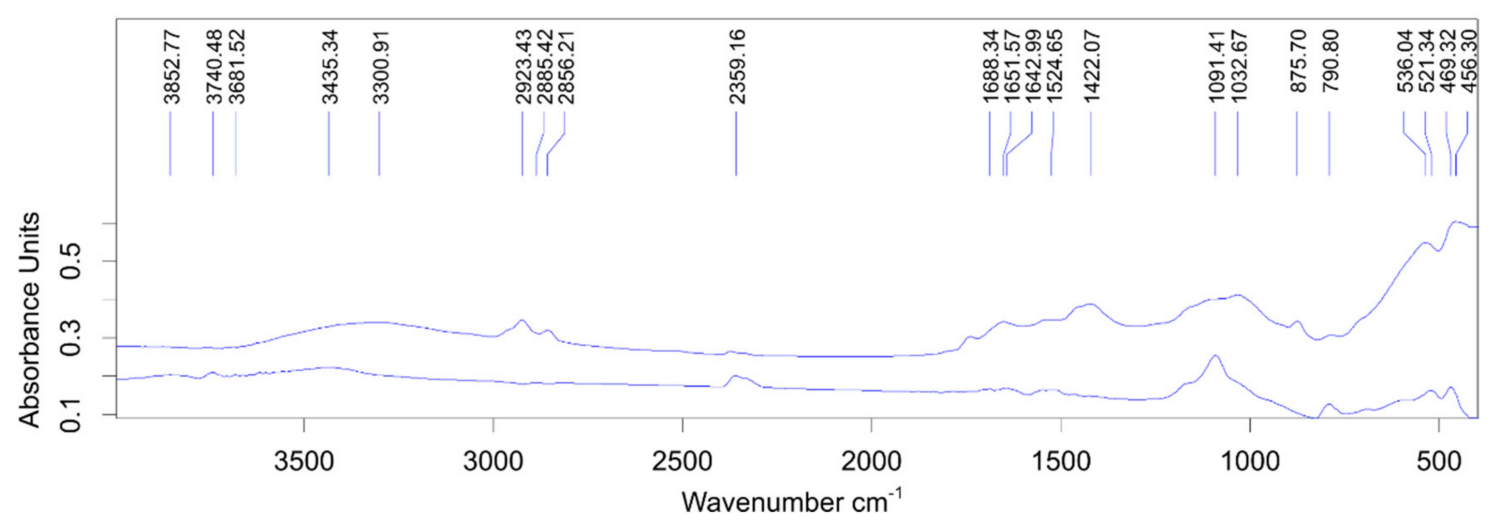

Figure 12. Infrared absorption spectra of manganese ore deposits: Bogach (upper), Zhaksy (lower).

When overlay the IRS of ore samples, a difference in the quantitative content of manganese minerals was found: pyrolusite, manganite and psilomelane fractions, which is expressed in different intensity of the absorption bands, but according to the specific presence, combination, and position of the characteristic absorption bands, it is necessary to conclude that they are present in the composition of the samples under study.

\section{Conclusions}

The findings obtained do not contradict and are in good agreement with the literature data regarding that Kazakhstan raw materials are classified as medium and low in terms of the manganese mineral content. The mineral matter in the Bogach deposit ore mainly consists of hollandite, cryptomelane, braunite, calcite, bixbyite, quartz. The Zhaksy deposit ore includes quartz, hollandite, bixbyite, pyrolusite. In this sample content of Mncontaining minerals is lower than in the Bogach deposit, only $54.5 \%$. That is reflected in the elemental content of studied ores. Therefore, Bogach ore includes (wt.\%) $\mathrm{C}(10.68), \mathrm{O}(32.00)$, $\mathrm{Mn}(43.26), \mathrm{Ca}(6.36), \mathrm{Si}(3.51), \mathrm{Na}(0.52), \mathrm{Al}(1.13), \mathrm{Mg}(0.69), \mathrm{K}(1.85)$. The elemental content of $\mathrm{Mn}$ in Zhaksy ore is two times lower. Zhaksy ore includes (wt.\%) C(23.77), $\mathrm{O}(32.1)$, $\mathrm{Mn}(21.81), \mathrm{Si}(10.52), \mathrm{Al}(5.13), \mathrm{K}(1.21), \mathrm{Fe}(5.47)$. The obtained data of the conducted spectral analysis indicate that both samples represent a polymineral heterogeneous structure.

The identity and homogeneity of the morphology of the surface and sub-layers of the samples, their nanoscale characteristics during electronic scanning provide a basis for differentiating the samples according to their component composition, depending on the source of origin. Thus, by the content of $\mathrm{Fe}$, the Bogach ore is related to manganese ores with a significant predominance of $\mathrm{Mn}$ over Fe. So, the coefficient $\mathrm{Mn} / \mathrm{Fe}$ for these ores is usually varied from 30 to 15 . At the same time, the Zhaksy ore belongs to the group of ferromanganese ores, where Fe is included in comparable or even equal amounts to manganese. $\mathrm{Mn} / \mathrm{Fe}$ in this ore sample is approximately 4 .

Iron in manganese ores is a useful impurity in smelting relatively poor Mn alloys, but for alloys with high manganese content, its amount in ores is limited; the richer it is manganese alloy, the lower the iron content in the ore should be. So, the presence of Fe in Zhaksy ore as a poor one is not an issue, but a significant amount of quartz can be a slag-forming component. With a high level of slag formation, the loss of manganese increases since it tends to partially pass into the slag in the form of a silicate phase. A 
feature of Mn ores of the Zhaksy deposit is the minimal content of harmful impurities such as $\mathrm{P}, \mathrm{S}$, and non-ferrous metals.

The Bogach ore as an oxide ore can be used without preliminary concentration for industrial use. As usual, manganese ores with Mn-Fe total content of $40-50 \%$ are massive ores from ore bodies, characterized by high capacity and well endurance of ore. The Zhaksy ore can be used in metallurgy only with concentration and is related to the class of easily beneficiated ores, which can easily be beneficiated without ragging through trommelling or washing with jigging.

Thus, the Bogach ore is related to second grade and can be used for smelting of silica manganese of II and III grades. The Zhaksy ore belongs to the fourth grade of ore and can be used for smelting of silicospiegel because it is a poor of Mn and more silica ore in comparison to manganese ore grades used for production of ferromanganese or spiegel.

Conducted research allows to conclude, that by phase-elemental content the Bogach ore can be used for obtaining trimanganese tetraoxide (hausmannite) pigment. Thus, manganese ores from West Sumatera deposit (Indonesia) are known as a raw material for trimanganese tetraoxide production by top-down method using grinding with a milling tool and high-temperature sintering $\left(1000^{\circ} \mathrm{C}\right)$ [27]. At room temperature the West Sumatera ore sample included 3 types of manganese oxide phase-pyrolusite, braunite, and coesite, which is similar to content of Bogach ore. Though the elemental content of $\mathrm{Mn}$ is highertill $84 \%$. Overall, the process of obtaining the required mineral phase can be controlled with variation of sintering mode.

Author Contributions: Conceptualization, J.B.K. and R.Z.S.; data curation, R.Z.S., J.B.K., A.K.Z. and B.B.M., methodology, R.Z.S., J.B.K. and Y.K.A.; validation, J.B.K. and B.B.M.; formal analysis, Y.K.A., A.K.S. and N.I.V.; resources, A.K.Z. and R.Z.S.; writing-original draft preparation, A.K.Z., R.Z.S.; writing-review and editing, J.B.K., Y.K.A., A.K.S. and N.I.V.; supervision, N.I.V.; project administration J.B.K.; funding acquisition, J.B.K. and R.Z.S.; investigation, J.B.K., R.Z.S., B.B.M., and A.K.Z.; software, R.Z.S. and A.K.Z.; visualization, R.Z.S. All authors have read and agreed to the published version of the manuscript.

Funding: The given research was carried out within the framework of a project funded by the Science Committee of the Ministry of Education and Science of the Republic of Kazakhstan (Grant No. AP08956244).

Conflicts of Interest: The authors declare no conflict of interest.

\section{References}

1. Fan, W.-G.; Gao, L. Preparation of $\mathrm{Mn}_{3} \mathrm{O}_{4}$ Nano Crystals in Dimethyl Sulfoxide (DMSO) Medium. Wuji Cailiao Xuebao J. Inorg. Mater 2006, 21, 789-792. [CrossRef]

2. Xia, Y.; Qiang, Z.; Lee, B.; Becker, M.L.; Vogt, B.D. Solid State Microwave Synthesis of Highly Crystalline Ordered Mesoporous Hausmannite $\mathrm{Mn}_{3} \mathrm{O}_{4}$ Films. CrystEngComm 2017, 19, 4294-4303. [CrossRef]

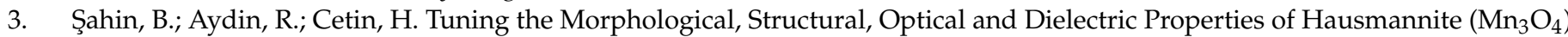
Films by Doping Heavy Metal Lead. Superlattices Microstruct. 2020, 143, 106546. [CrossRef]

4. Piao, J.; Duan, S.; Mao, Y.; Wang, J.; Cao, A.M.; Zhang, L. Stabilization of the Energetic Al Powder through Uniform and Controlled Surface Coating for Promoting Its Energy Output. Surf. Coat. Technol. 2020, 389, 125603. [CrossRef]

5. Narayani, L.; Jagadeesha Angadi, V.; Sukhdev, A.; Challa, M.; Matteppanavar, S.; Deepthi, P.R.; Mohan Kumar, P.; Pasha, M. Mechanism of High Temperature Induced Phase Transformation and Magnetic Properties of $\mathrm{Mn}_{3} \mathrm{O}_{4}$ Crystallites. J. Magn. Magn . Mater. 2019, 476, 268-273. [CrossRef]

6. Wang, Q.; Li, Y.; Shen, Z.; Liu, X.; Jiang, C. Facile Synthesis of Three-Dimensional $\mathrm{Mn}_{3} \mathrm{O}_{4}$ Hierarchical Microstructures for Efficient Catalytic Phenol Oxidation with Peroxymonosulfate. Appl. Surf. Sci. 2019, 495, 143568. [CrossRef]

7. Barreto, M.S.C.; Elzinga, E.J.; Alleoni, L.R.F. Hausmannite as Potential As(V) Filter. Macroscopic and Spectroscopic Study of As(V) Adsorption and Desorption by Citric Acid. Environ. Pollut. 2020, 262, 114196. [CrossRef] [PubMed]

8. Stoševski, I.; Bonakdarpour, A.; Fang, B.; Voon, S.T.; Wilkinson, D.P. Hausmannite $\mathrm{Mn}_{3} \mathrm{O}_{4}$ as a Positive Active Electrode Material for Rechargeable Aqueous Mn-Oxide/Zn Batteries. Int. J. Energy Res. 2020, 45, 220-230. [CrossRef]

9. Stosevski, I.; Bonakdarpour, A.; Voon, S.T.; Wilkinson, D.P. Electrochemical Activation of $\mathrm{Mn}_{3} \mathrm{O}_{4}$ (Hausmannite) for a Rechargeable Aqueous Zn/Mn-Oxide Battery for Energy Storage Applications. In Proceedings of the 2019 4th International Conference on Smart and Sustainable Technologies (SpliTech), Split, Croatia, 1 June 2019; pp. 1-5. [CrossRef] 
10. Sun, M.; Li, D.; Wang, Y.; Liu, W.; Ren, M.; Kong, F.; Wang, S.; Guo, Y.; Liu, Y. $\mathrm{Mn}_{3} \mathrm{O}_{4} @ \mathrm{NC}$ Composite Nanorods as a Cathode for Rechargeable Aqueous Zn-Ion Batteries. ChemElectroChem 2019, 6, 2510-2516. [CrossRef]

11. Naiknaware, A.G.; Chavan, J.U.; Kaldate, S.H.; Yadav, A.A. Studies on Spray Deposited Ni Doped $\mathrm{Mn}_{3} \mathrm{O}_{4}$ Electrodes for Supercapacitor Applications. J. Alloys Compd. 2019, 774, 787-794. [CrossRef]

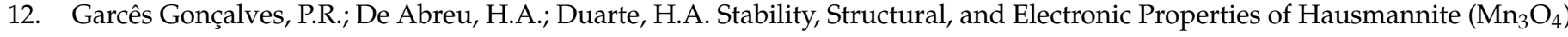
Surfaces and Their Interaction with Water. J. Phys. Chem. C 2018, 122, 20841-20849. [CrossRef]

13. Sukhdev, A.; Challa, M.; Narayani, L.; Manjunatha, A.S.; Deepthi, P.R.; Angadi, J.V.; Mohan Kumar, P.; Pasha, M. Synthesis, Phase Transformation, and Morphology of Hausmannite $\mathrm{Mn}_{3} \mathrm{O}_{4}$ Nanoparticles: Photocatalytic and Antibacterial Investigations. Heliyon 2020, 6, e03245. [CrossRef] [PubMed]

14. Ahmed, K.A.M.; Huang, K. Formation of $\mathrm{Mn}_{3} \mathrm{O}_{4}$ Nanobelts through the Solvothermal Process and Their Photocatalytic Property. Arab. J. Chem. 2019, 12, 429-439. [CrossRef]

15. Giraldo, O.; Arias, N.P.; Becerra, M.E. Electrical Properties of $\mathrm{TiO}_{2}$-Pillared Bidimensional Manganese Oxides. Appl. Clay Sci. 2017, 141, 157-170. [CrossRef]

16. Kulkarni, S.; Puthusseri, D.; Thakur, S.; Banpurkar, A.; Patil, S. Hausmannite Manganese Oxide Cathodes for Supercapacitors: Surface Wettability and Electrochemical Properties. Electrochim. Acta 2017, 231, 460-467. [CrossRef]

17. Singh, N.H.; Bera, A.; Debnath, A.; Saha, B. Mixed Phase Crystalline Hausmannite and Manganese Ferrite Nanoparticles with Magnetic Properties for Environmental Application. Mater. Today Proc. 2018, 5, 2300-2305. [CrossRef]

18. Karpagavalli, S.; Kennady Vethanathan, S.J.; Perumal, S. Effect of Nickel Doping on the Structural, Optical, Electrochemical and Magnetic Properties of Hausmannite $\left(\mathrm{Mn}_{3} \mathrm{O}_{4}\right)$ Nanoparticles. Int. J. Nanopart. 2019, 11, 305-321. [CrossRef]

19. Deraz, N.M. Green Synthesis, Characterization and Magnetic Properties of Hausmannite Nanoparticles. Acta Phys. Pol. A 2019, 136, 147-150. [CrossRef]

20. Rani, B.J.; Ravina, M.; Ravi, G.; Ravichandran, S.; Ganesh, V.; Yuvakkumar, R. Synthesis and Characterization of Hausmannite $\left(\mathrm{Mn}_{3} \mathrm{O}_{4}\right)$ Nanostructures. Surf. Interfaces 2018, 11, 28-36. [CrossRef]

21. Karimi, M.; Eshraghi, M.J. One-Pot and Green Synthesis of $\mathrm{Mn}_{3} \mathrm{O}_{4}$ Nanoparticles Using an All-in-One System (Solvent, Reactant and Template) Based on Ethaline Deep Eutectic Solvent. J. Alloys Compd. 2017, 696, 171-176. [CrossRef]

22. Bastami, T.R.; Entezari, M.H. Sono-Synthesis of $\mathrm{Mn}_{3} \mathrm{O}_{4}$ Nanoparticles in Different Media without Additives. Chem. Eng. J. 2010, 164, 261-266. [CrossRef]

23. Dhaouadi, H.; Madani, A.; Touati, F. Synthesis and Spectroscopic Investigations of $\mathrm{Mn}_{3} \mathrm{O}_{4}$ Nanoparticles. Mater. Lett. 2010, 64, 2395-2398. [CrossRef]

24. Du, J.; Li, W.-Y.; Tao, C.-Y.; Liu, Z.-H.; Sun, D.-G. Study on Microwave-Assisted Preparation of Ultrafine $\mathrm{Mn}_{3} \mathrm{O}_{4}$. Yadian Yu Shengguang Piezoelectr. Acoustoopt. 2008, 30, 33-35.

25. Lu, W.; He, K.; Zhao, G.; Song, B.; Zhou, J.; Dong, W.; Han, G. Top-down Synthesis of Sponge-like $\mathrm{Mn}_{3} \mathrm{O}_{4}$ at Low Temperature. RSC Adv. 2019, 9, 22772-22778. [CrossRef]

26. Koga, H. Preparation of the Active Manganese(IV) Oxide for Dry Batteries by the Thermal Decomposition of Manganese(II) Sulfate. Nippon Kagaku Kaishi 1983, 1983, 18-22. [CrossRef]

27. Ratnawulan; Prasetyo, F.; Fauzi, A.; Ramli. Synthesis and Characterization Hausmannite $\left(\mathrm{Mn}_{3} \mathrm{O}_{4}\right)$ Nanoparticle of Manganese Ores Prepared By High-Energy Milling. Int. J. Adv. Sci. Technol. 2020, 29, 8332-8339.

28. Cheraghi, A.; Becker, H.; Eftekhari, H.; Yoozbashizadeh, H.; Safarian, J. Characterization and Calcination Behavior of a Low-Grade Manganese Ore. Mater. Today Commun. 2020, 25, 101382. [CrossRef]

29. Zhanykulov, Z.E. Annual Report of JSC "Temirtau Electric Metallurgical Plant"; JSC "Temirtau Electric Metallurgical Plant": Temirtau, Kazakhstan, 2018.

30. Directory of deposits of Kazakhstan. Available online: http://info.geology.gov.kz/ru/informatsiya/spravochnik-mestorozhdenijkazakhstana (accessed on 25 November 2021).

31. Gasik, M.I.; Schuvaev, S.P. IR-spectroscopic study of the mineral composition of concentrates manganese ore and slag concentrates the spent slurry tank. Metall. Min. Ind. 2016, 5, 23-30.

32. Palchik, N.A.; Moroz, T.N.; Grigoreva, T.N. Features of the Composition and Structural Transformations of Manganese Minerals of Lake Bolshoe Miassovo (Southern Urals). J. Struct. Chem. 2014, 55, 798-804. [CrossRef]

33. Van Snick, W.; Aibuldinov, Y.K.; Dehaen, W. An Efficient Synthetic Route towards Novel Thienobenzothiazoles, Thienobenzothiazepines, and Thienobenzothiazines. Tetrahedron 2013, 69, 4176-4184. [CrossRef]

34. Kang, L.; Zhang, M.; Liu, Z.-H.; Ooi, K. IR Spectra of Manganese Oxides with Either Layered or Tunnel Structures. Spectrochim. Acta Part A Mol. Biomol. Spectrosc. 2007, 67, 864-869. [CrossRef]

35. Pani, S.; Singh, S.K.; Mohapatra, B.K. Vibrational Spectroscopic Study for Qualitative Assessment of Mn-Oxide Ore: Vibrational Spectroscopic Study of Mn Ore. Resour. Geol. 2016, 66, 12-23. [CrossRef]

36. Swami, M.C.; Jayasheela, H.M.; Hulsure, V.C. Infrared Spectra of Manganese Ores from Deogiri of Sandur Schist Belt Area Karnataka India. Int. J. Res. Advent Technol. 2014, 2, 341-344.

37. Potter, R.M.; Rossman, G.R. The Tetravalent Manganese Oxides: Identification, Hydration, and Structural Relationships by Infrared Spectroscopy. Am. Mineral. 1979, 64, 1199-1218.

38. Mohapatra, B.K.; Paul, A.K.; Sahoo, R.K. Ferromanganese Oxide Ores of Western Koira Valley, Orissa, India: An Infrared Spectroscopy Study. Mineral. J. 1990, 15, 105-118. [CrossRef] 